\title{
Assessment on Regional Flood Risk Trend in Northern Region of Malaysia: Case Study in Muda River Basin, Kedah
}

\author{
Marhanisa Abd Halim¹, Ahmad Shakir Mohd Saudi ${ }^{1,2 *}$, Mohd Khairul Amri Kamarudin ${ }^{3}$, Muaz Mahmud ${ }^{4}$, Arvind \\ Bala Krishnan', Khairul Nizam Mohd Isa ${ }^{1}$ \\ ${ }^{1}$ Institute of Medical Science Technology, Universiti Kuala Lumpur, 43000 Kajang, Selangor, Malaysia \\ ${ }^{2}$ Cybersecurity and System Unit, Faculty Science and Technology, Universiti Sains Islam Malaysia,71800 Nilai, Negeri Sembilan, Ma- \\ laysia \\ ${ }^{3}$ Faculty of Applied Social Science, Universiti Sultan Zainal Abidin, Gong Badak Campus, 21300 Kuala Nerus, Terengganu, Malaysia \\ ${ }^{4}$ Lancaster University Management School Lancaster, LA1 4YX, United Kingdom \\ *Corresponding authorE-mail: ahmadshakir@unikl.edu.my
}

\begin{abstract}
Flood is a major issue during monsoon season in Northern region of Malaysia especially in Muda River Basin. This study focused on the specific hydrology parameters that lead to the flood events in Muda River Basin, Kedah. There were 4 hydrologic parameters for thirty years of collected data from selected hydrology monitoring stations provided by Department of Irrigations and Drainage, Malaysia. The study applied Principal Component Analysis (PCA) and result shown that stream flow and suspended solid stand with highest correlation of coefficient variables with the changes of water level in the study area. Statistical Process Control (SPC) applied in this study was to determine the control limit for every selected parameter obtained from PCA. The Upper Control Limit value for water level reported from SPC analysis in the study area was $7.568 \mathrm{~m}$ and starting from this level and above, the risk of flood is high to occur in the study area. This research proved that the flood risk model created in this study was accurate and flexible for flood early warning system at Muda River Basin.
\end{abstract}

Keywords: Principal Component Analysis; Statistical Process Control; Control Limit; Flood Risk Model.

\section{Introduction}

A flood can be characterized as any high water stream that overwhelms the natural and also artificial banks in any part of the waterway system. Along these lines, when a waterway bank is overtopped, the water may reaches out finished the floodplain and for the most part turns into a risk to the general public $[1,2]$. During flood occurrence, it majorly affects individuals as it upsets their everyday activities and the effects can keep going for seven days in the coming years, environmental change is probably going to make the circumstance much additionally difficult $[3,4]$.

It can be partitioned into naturally-occurring floods, which happens amid short, high intensity precipitation and human-prompted flood, in which disposal of solid wastes leads to obstruction or blockage of the drainage and irrigation system. The management of surge is a complex, multi-task approach that needs a balance amongst timeliness and cost-adequacy [5]. Malaysia experienced the most decimating catastrophic event which is flood. All through Malaysia, including Sabah and Sarawak, there is an aggregate of 189 stream bowls with the principle channels streaming specifically toward the south China Ocean and 85 of them are prone to recurrent flooding.

Flood in Malaysia have been arranged into two classifications by the Malaysian Drainage and Irrigation Department, for example, flash flood and monsoon flood [6, 7]. In light of the hydrological viewpoints, the unmistakable contrast between those two catastrophes is the period taken by the stream to retreat to the ordinary level. Flash floods take about a few hours to come back to the ordinary water level, while storm surge can keep going for a month. This flood event influenced around 4.82 million individuals which is about $22 \%$ of the total population of the nation [1]. In Kedah, Muda river which is situated in northern region of Malaysia is the longest river with the length of $180 \mathrm{~km}$. Its catchment area is $4210 \mathrm{~m}^{3}$ and its upstream flow was originating from the northern sloping zone of the state. In Muda river system, there are 3 important tributaries which are Ketil river, Sedim river as well as Chepir river [6]. It is the most important source of water contributor for the northern states $[8,9]$.

New logging trail was found together with abundant number of logs in the Ulu Kedah forest reserve. All of the plants and trees in the forest act as catchment area that absorbs the rains. When there is exposed ground due to illegal logging activities, the soil sediment and suspended solid erodes and silting up into the river [1012]. It resulted in shallower rivers with increasing speed of stream flow which causes the water level to arise, causing devastating flood.

In this research, in order to determine the specific hydrology parameter that leads to major contribution of flood in Muda River, there are four parameters that will be assessed in 2 different areas. The relationship between the hydrological variables in this study was determined through the application of the correlation test in Principle Component Analysis (PCA). Meanwhile, to clarify the flood risk pattern recognition, Statistical Process Control (SPC) was applied. 


\section{Materials and Methods}

\subsection{Study Area}

Muda River Basin is the wellspring of water supply for the two states of Kedah and Penang. From this river basin, the great water demand projection has been made with the intention of to satisfy the need of water resources from the river basin. It is also a fundamental sources of water supply for farming and agricultural purposes as the area along the river basin is covered by paddy field, where it requires a lot of water utilization from the river basin $[13,14]$.

The geology of study territory is positioned at the coordinates of $5^{\circ} 06^{\prime} \mathrm{N}$ and $100^{\circ} 17^{\prime} \mathrm{E}$. The river basin is situated in the north-west part in Peninsular Malaysia and the catchment area is around $4,210 \mathrm{~m}^{3}$. The study area has atmosphere shifting from the rainstorm season where it covers the aggregate region of $11,252 \mathrm{~km}^{2}$ and the zone incorporates three states which are Kedah, Perlis and Penang.

During the North-East storm season, it will get a small amount of precipitation because of high mountainous area in the central part of the Peninsular of Malaysia [15-18].The topography of the Muda River Basin and the monitoring station along the waterway bowl is represented in Figure 1 and Table 1. Department of Drainage and Irrigation (DID) provided the secondary hydrological data for the year 1982 until 2012, which incorporate rainfall, suspended solid, stream flow and water level.

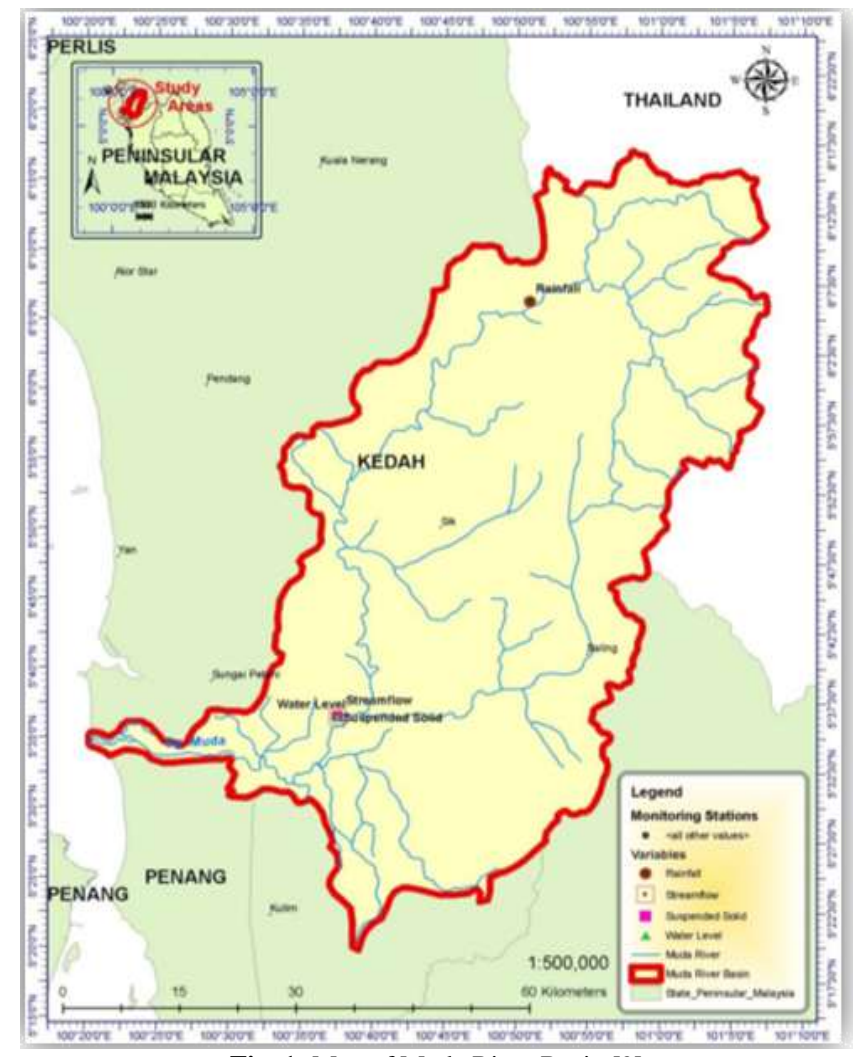

Fig. 1: Map of Muda River Basin [9]

Table 1: Location Station Monitoring at Pahang River Basin

\begin{tabular}{|c|c|c|c|c|}
\hline $\begin{array}{c}\text { Station } \\
\text { No. }\end{array}$ & Latitude & Longitude & $\begin{array}{c}\text { Name of } \\
\text { Station }\end{array}$ & Variables \\
\hline $\begin{array}{c}\text { Site } \\
6108001\end{array}$ & $5^{\circ} 06^{\prime} 48^{\prime \prime} \mathrm{N}$ & $100^{\circ} 01^{\prime} 55^{\prime \prime} \mathrm{E}$ & $\begin{array}{c}\text { Kompleks } \\
\text { Rumah Muda }\end{array}$ & Rainfall \\
\hline $\begin{array}{c}\text { Site } \\
5606410\end{array}$ & $5^{\circ} 12^{\prime} 57^{\prime \prime} \mathrm{N}$ & $100^{\circ} 27^{\prime} 16^{\prime \prime} \mathrm{E}$ & $\begin{array}{c}\text { Jambatan } \\
\text { Syed Omar }\end{array}$ & $\begin{array}{c}\text { Suspended } \\
\text { Solid }\end{array}$ \\
\hline $\begin{array}{c}\text { Site } \\
5606510\end{array}$ & $5^{\circ} 17^{\prime} 25^{\prime} \mathrm{N}$ & $100^{\circ} 39^{\prime} 29^{\prime \prime} \mathrm{E}$ & $\begin{array}{c}\text { Jambatan } \\
\text { Syed Omar }\end{array}$ & $\begin{array}{c}\text { Stream } \\
\text { Flow }\end{array}$ \\
\hline $\begin{array}{c}\text { Site } \\
5606410\end{array}$ & $5^{\circ} 18^{\prime} 32^{\prime \prime} \mathrm{N}$ & $100^{\circ} 40^{\prime} 23^{\prime \prime} \mathrm{E}$ & $\begin{array}{c}\text { Jambatan } \\
\text { Syed Omar }\end{array}$ & $\begin{array}{c}\text { Water } \\
\text { Level }\end{array}$ \\
\hline
\end{tabular}

\subsection{Statistical Analysis/ Pre-Processed Data}

\subsubsection{Chemometric Technique}

Chemometric technique such as application of Factor Analysis is able to see the reduction of variables into a set of factors for further analysis. Researcher rarely collect and analyze data with an idea about how the variables are related and application of these method able to make comparison which variables that effecting the most towards the change of the hydrological modeling at the study area with a cheap cost and quicker compare to other technique [19]. The reduction of variables into a set of factors for further analysis can be observed using Chemometric technique, such as the utilization of Factor Analysis. With this technique, variables with the biggest influence in the change of the hydrological modeling at the study area can be compared in a cost effective and quicker manner compared to other techniques.

\subsubsection{Principle Component Analysis (PCA)}

The application of PCA in this study is to determine the large number of variables into smaller sets. Factor analysis variables and latent construct are measured will establish between the two elements and validity evidence of self-reporting scales. This method reduces the number of variables, examines on the structure or relationship between variables in the hydrological data and detects any the non-dimensionality of theoretical construct. It also includes the multi co-linearity which involves two or more variables that re-correlated, which was carried out in this study. On the other hand, the PCA will look into the relationship between the variables and identify the strongest relationship. Based on the results, it able to point out which variables involve in development that causes the biggest impacts on hydrological modeling at the Pahang River Basin [19].

The PCA was carried out by using XLSTAT 2017 software and the results are used for discussion. Equation used refers in (1):

$$
Z i j=a i^{1} x j^{1}+a i^{2} x j^{2}+a i^{3} x j^{3}+a i m x
$$

$\mathrm{Z}=$ Component score,

$\mathrm{a}=$ Component loading,

$\mathrm{x}=$ Measured of variables,

$\mathrm{I}=$ Component number,

$\mathrm{m}=$ Total variables

\section{Statistical Process Control (SPC)}

Time Series Analysis is very important in prediction of water level at the study area. By using this method, it will evaluate on the process from the performance of the analyzed data efficiently. It produced three important results, which important in predicting the hydrological modeling in the future, and those result were Upper Control Limit (UCL), Control Limit (CL) and Lower Control Limit (LCL) in the control chart is represented within the range value of a set of data. The Control Chart has the ability to uncover some trends and patterns, showing actual data deviations from the historical baseline and dynamic threshold, being able to capture unusual resource usage and becoming the best base lining to show how actual data are deviated from historical baseline. The equation used refer in (2)-(3):

Moving Range $=$ Plot: MRt for $\mathrm{t}=2,3, \ldots, \mathrm{m}$.

$\mathrm{MR}=$ average moving range

$\mathrm{t}=$ time

$\mathrm{m}=$ individual values

Average Value: $\tilde{\boldsymbol{x}}=\underline{\sum_{i=1}^{m} x_{i}}$ 
$\bar{X}=$ moving range

$\mathrm{m}=$ individual values

$\boldsymbol{x}_{\tilde{i}}=$ individual values

\section{Results and Discussion}

\subsection{Identification of the Significant Factor of Flood Event}

In the identification of significant factors, the result of factor loading must have eigenvalue of more than 0.7. With the value, it is considered a strong loading factor and it is significant to be used as a strong factor in the analysis process. In Table 2, it shows the results of the factor loading.

In Factor 1 column, the factor loading result of stream flow has the strongest value of $0.968,0.934$ for suspended solid and 0.849 for water level. Meanwhile in Factor 2, rainfall was the strongest factor loading with the result value of 0.914 . Nevertheless, all of the results for another 3 variables did not have strong factor loading where the result for stream flow was -0.149 , while suspended solid was -0.316 and lastly water level with the value of 0.510 . Based on Factor 1 result column, it shows that each rise of suspended solid in Muda river basin will significantly rises the stream flow. On the other hand, the result also shows that significant increment of the speed for stream flow also increases the water level.

From Factor 2 column, the result shows that the strongest factor loading was rainfall, even though it has the highest rate, it only gives minor impact towards the other hydrological variables in this study. It does not have any substantial influence towards the fluctuations in stream flow, suspended solid as well as water level. All elements showed the strong factor loading with result of factor loading of more than 0.7. Suspended solid component proved to have the most solid impact for the formation of flood together with stream flow and water level, which conveys a higher correlation coefficient in the analysis [20,21].

The high level of suspended solid might be happening due to mega project development along the Muda river. Recently in 2017, a reporter found new logging trail and abundant number of $\operatorname{logs}$ in the Ulu Kedah forest reserve. All of the trees act as catchment area that absorb the rains. When there is exposed ground due to logging activities, the soil sediment and suspended solid erodes and silting up into the river. It resulted in shallower rivers with increasing speed of stream flow which causes the water level to arise, causing devastating flood [22].

Table 2: Correlation of Coefficient Result between Variables and Factors of Principle Component Analysis from 1982-2012 in Muda River Basin

\begin{tabular}{|c|c|c|}
\hline Variables & F1 & F2 \\
\hline Stream Flow & 0.968 & -0.149 \\
\hline Suspended Solid & 0.934 & -0.120 \\
\hline Water Level & 0.849 & -0.135 \\
\hline Rainfall & 0.406 & 0.914 \\
\hline
\end{tabular}

\begin{tabular}{|l|c|c|}
\hline \multicolumn{1}{|c|}{ Eigenvalue } & 2.694 & 0.890 \\
\hline Variability (\%) & 67.36 & 22.24 \\
\hline Cumulative (\%) & 67.36 & 89.611 \\
\hline
\end{tabular}

\subsection{Flood Control Warning System}

From the analysis by SPC for the study area, the results obtained for stream flow were tabulated in Table 3 and also in Figure 2. The Lower Control Limit (LCL) was $39.295 \mathrm{~m} / \mathrm{s}$, the Center Limit (CL) was $70.539 \mathrm{~m} / \mathrm{s}$ and the Upper Control Limit (UCL) was $101.783 \mathrm{~m} / \mathrm{s}$. These finding results are crucial for the process of refining flood early warning system in Muda River Basin. In Figure 2, the highest peak of stream flow has the value of 127.200 $\mathrm{m} / \mathrm{s}$ which is on October in year 2008. In this particular year, Kedah face massive flood and destruct thousands of houses and infrastructures along Muda river basin. This is due to illegal logging activities near Ahning, Pedu and Muda dams.

As for suspended solid, the result was 294.897 tonnes/day of the LCL, the CL was 1202.902 tonnes/day and the UCL was 2110.907 tonnes/day. The results were shown in Table 3 and Figure 3. The suspended solid pattern can be visibly seen and this changes majorly impacted the stream flow as well as water level in Muda river basin since the correlation is strong among those 3 variables. Based on Figure 3, the pattern of the graph was the highest in November 1998 with the value of 9720.300 tonnes/day. This is due to exploitation to the forest near Pedu Dam.

Next, the water level result in Muda River Basin was $6.808 \mathrm{~m}$ of the LCL, the CL was about $7.188 \mathrm{~m}$ and the UCL was $7.568 \mathrm{~m}$. The results obtained in Table 3 and Figure 4 indicate Muda River flood patterns. If the data plotted is above the UCL value, then it may lead to overflow of water from the riverbed thus causes flood. Meanwhile, water level that is in range of CL is categorized to be in a safe zone and the river basin is able to contain the water tolerably. In Figure 4, the reading of the water level is at the highest peak in year 2000 with the value of $10.050 \mathrm{~m}$.

Lastly, based on Table 3 and Figure 5, both of them shows the entire rainfall result of all of the control limit values in Muda river basin. The LCL value was $-11.050 \mathrm{~mm}$, the CL was $6.406 \mathrm{~mm}$ and as for UCL, the value was $23.862 \mathrm{~mm}$. These rainfall patterns can be seen in Figure 5 where the peak was at 127.200 in year 2008 . The result was rare and beyond the ordinary limit thus it was considered as peculiar condition.

From the entire control limit results obtained by SPC analysis, it gives huge advantage for the Kedah local authorities to implement a constant monitoring system to establish initial actions depending on the stream flow as well as the suspended solid results [23, 24]. With the existing pattern in Muda river basin, early warning system can be done efficiently. Control limit system gives many benefits, despite from serving the economic sector for the preparation for flood; it also helps in sensing the possibility of scarcity. This advantage is vital since Muda river basin is the key water supply desired by paddy fields in northern region of Malaysia. Hence, optimal water supply can sustain the maximum stock of rice for communities all over Malaysia.

Table 3: Result of Statistical Process Control for Muda River Basin

\begin{tabular}{|c|c|c|c|c|c|c|}
\hline Area & Points Plotted & Lower Control Limit & Central Limit & Upper Control Limit & Limit Sigma & Sample Size \\
\hline Stream Flow & Individual & $39.295 \mathrm{~m} / \mathrm{s}$ & $70.539 \mathrm{~m} / \mathrm{s}$ & $101.783 \mathrm{~m} / \mathrm{s}$ & Moving Range & 1 \\
\hline Suspended Solid & Individual & 294.897 tonnes/day & 1202.902 tonnes/day & 2110.907 tonnes/day & Moving Range & 1 \\
\hline Water Level & Individual & $6.808 \mathrm{~m}$ & $7.188 \mathrm{~m}$ & $7.568 \mathrm{~m}$ & Moving Range & 1 \\
\hline Rainfall & Individual & $-11.050 \mathrm{~mm}$ & $6.406 \mathrm{~mm}$ & $23.862 \mathrm{~mm}$ & Moving Range & 1 \\
\hline
\end{tabular}




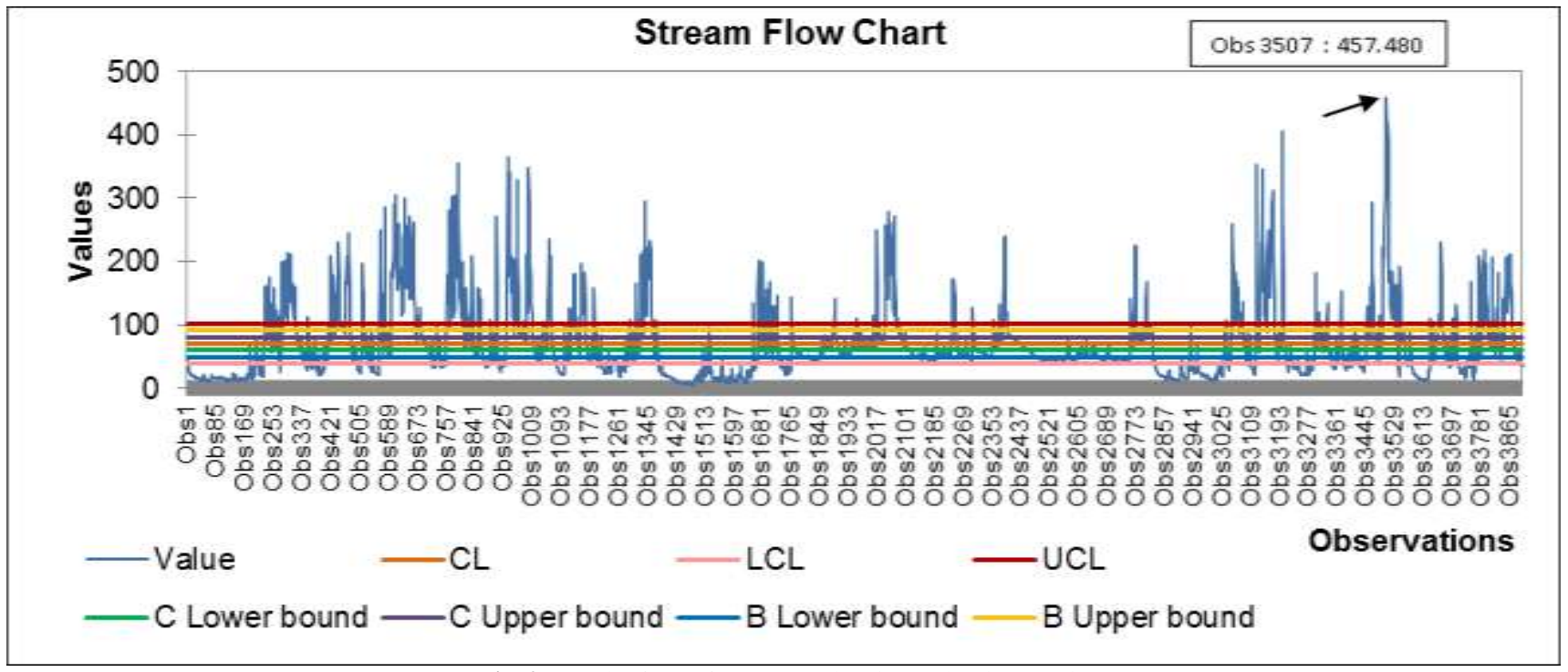

Fig. 2: Result of SPC for Stream Flow in Muda River Basin

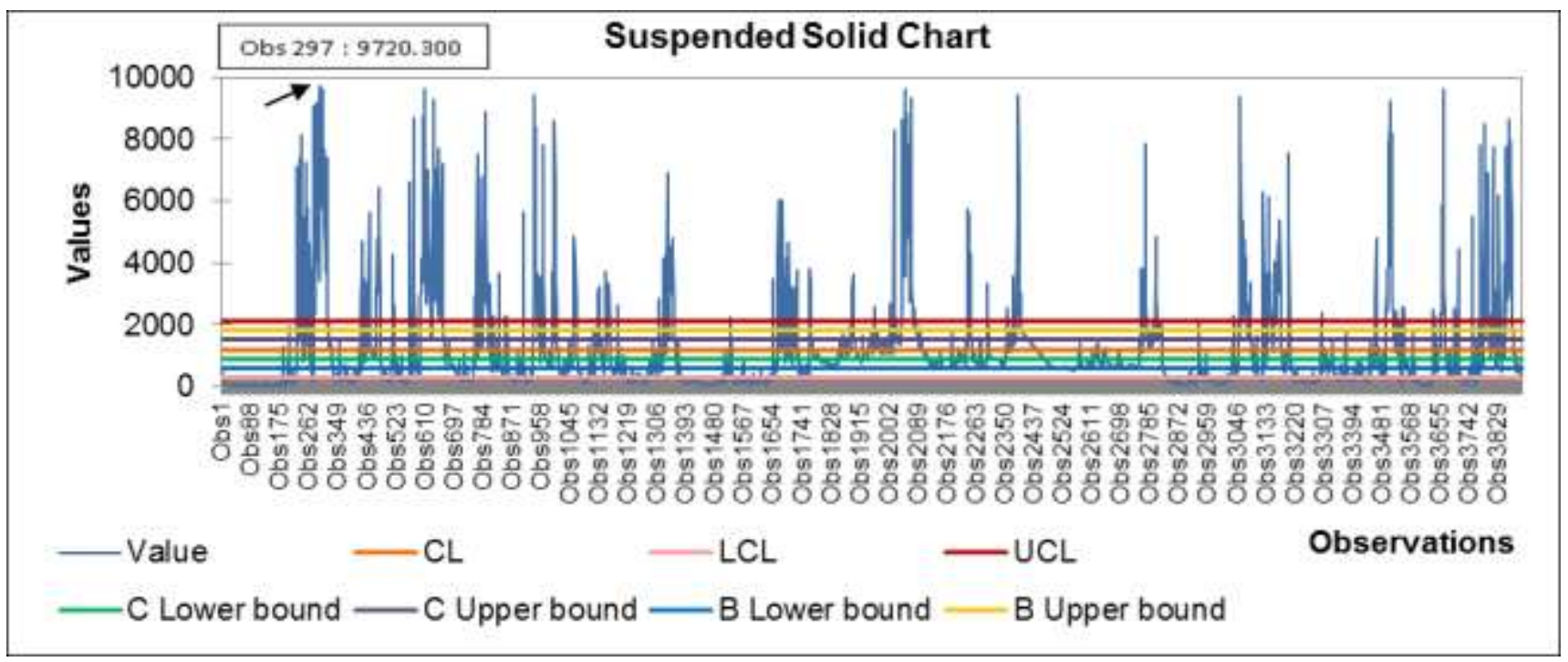

Fig. 3: Result of SPC for Suspended Solid in Muda River Basin

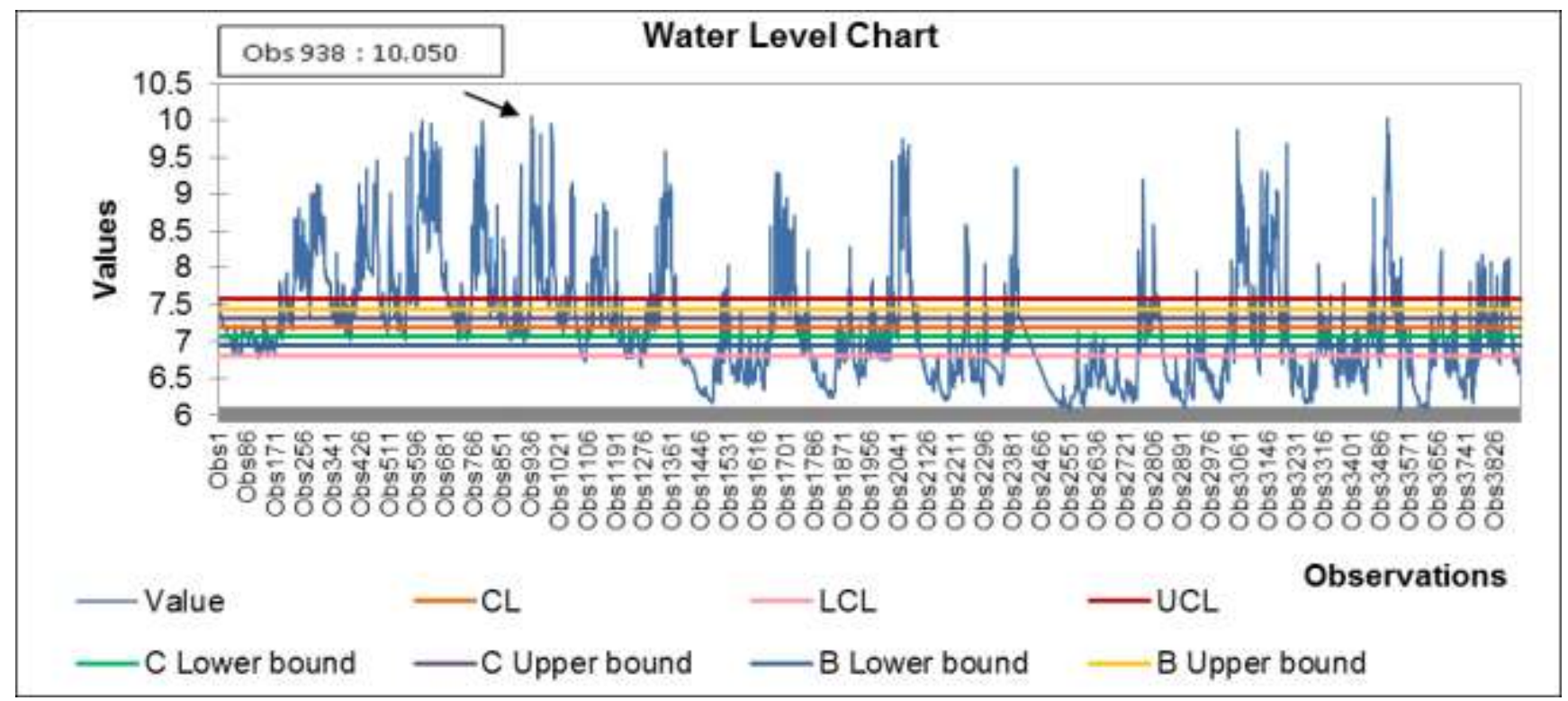

Fig. 4: Result of SPC for Water Level in Muda RiverBasin 


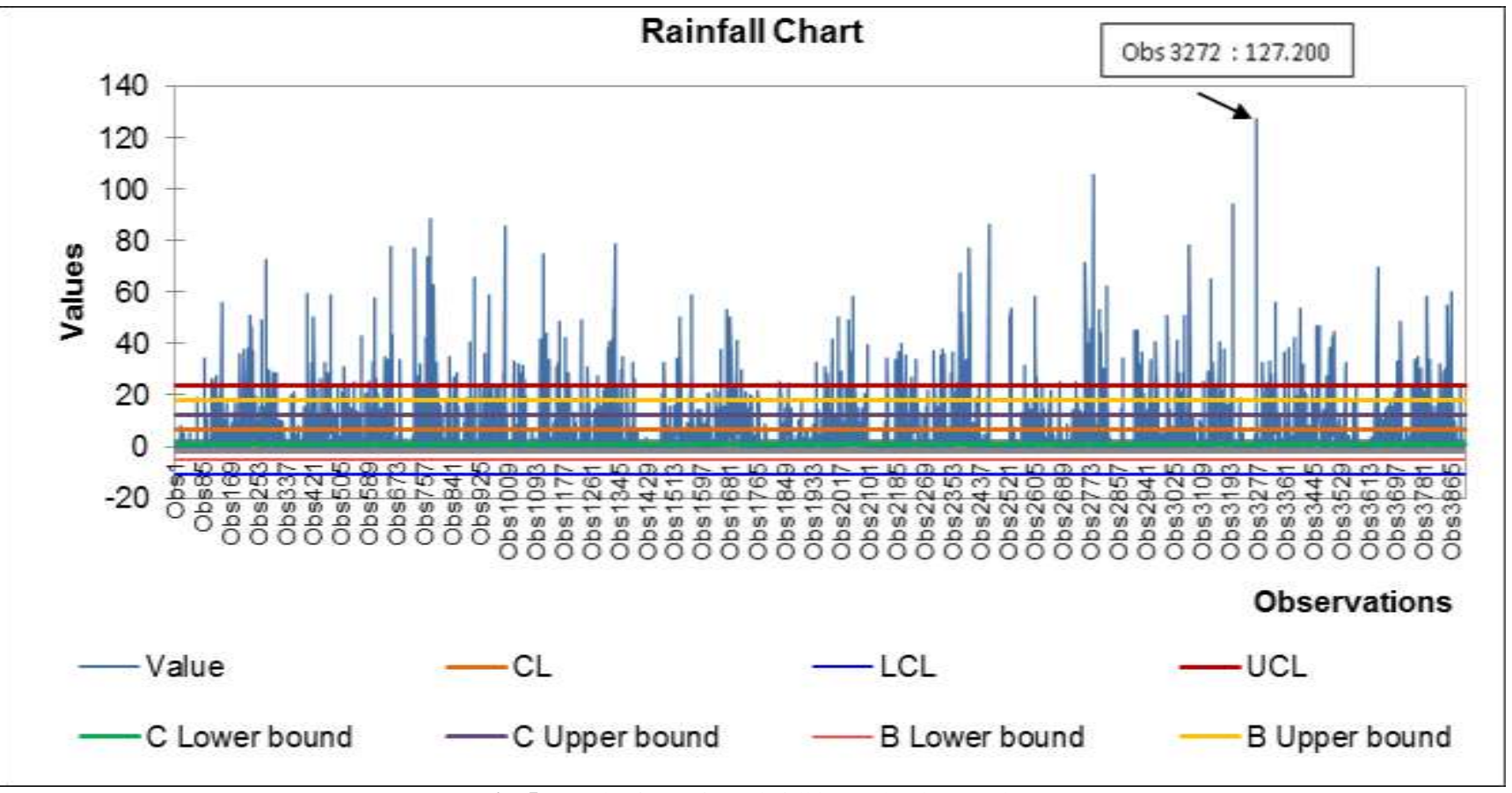

Fig. 5: Result of SPC for Rainfall in Muda River Basin

\section{Conclusion}

From the analysis, the most noteworthy factor in the association of significant hydrology parameters in this study was gained and they are functional for the advancement of risk models in developing warning alert system at Muda river basin. The variables with the strongest correlation which are stream flow and suspended solid were verified statistically that stresses the flood pattern recognition.

Flood risk pattern was recognized by the application of SPC which has provided chart for each parameter. The spike of peak can be observed effortlessly. The UCL, LCL and CL were extremely vital to ensure that each parameter do not exceed the maximum limit that the river could stand. When the maximum limit control is nearly reached, this system can act as mitigating measure to give warning to the communities in the area to prepare themselves in overcoming flood thus saving their important documents and evacuate the area hurriedly.

\section{Acknowledgement}

The authors acknowledge the Department of Irrigation and Drainage (DID) Malaysia under Ministry of Natural Resources and Environment as reliable sources and for giving us permission and supporting us by providing the hydrological data.

\section{References}

[1] Farid, A. M., Lubna, A., Choo, T. G., Rahim, M. C., \& Mazlin, M (2016). A review on the chemical pollution of Langat River, Malaysia. Asian Journal of Water, Environment and Pollution, 13(1), 9-15.

[2] Gasim, M. B., Toriman, M. E., Idris, M., Lun, P. I., Kamarudin, M. K. A., Nor Azlina, A. A., Mokhtar, M., \& Mastura, S. A. S. (2013). River flow conditions and dynamic state analysis of Pahang River. American Journal of Applied Sciences, 10(1), 42-57.

[3] Saudi, A. S. M., Kamarudin, M. K. A., Azid, A., \& Rizman, Z. (2017). Flood Risk Index Pattern Assessment: Case study in Langat River. Journal of Fundamental and Applied Sciences, 9(2S), 12-27.

[4] Kamarudin, M. K. A., Toriman, M. E., Wahab, N. A., Hafizan, J., Endut, A., Umar, R., \& Gasim, M. B. (2017). Development of stream classification system on tropical areas with statistical approval in Pahang River Basin, Malaysia. Desalination and water Treatment, 96, 237-254.
[5] Saifulsyahira, J., Edre, M. A., AF, A. F., \& Juni, M. H. (2016). Governance of flood disaster management: Malaysian case study. International Journal of Public Health and Clinical Sciences, 3(1), 17-30.

[6] Ghani, A. A., Ali, R., Zakaria, N. A., Hasan, Z. A., Chang, C. K., \& Ahamad, M. S. S. (2010). A temporal change study of the Muda River system over 22 years. International Journal of River Basin Management, 8(1), 25-37.

[7] Kamarudin, M. K. A., Toriman, M. E., Wahab, N. A., Rosli, H., Ata, F. M., \& Faudzi, M. N. M. (2017) Sedimentation study on upstream reach of selected rivers in Pahang River Basin, Malaysia. International Journal on Advanced Science, Engineering and Information Technology, 7(1), 35-41.

[8] Lee, K. F. (2009). A background study: Economic benefits of the Muda water catchment. http://awsassets.wwf.org.my/downloads/economic_benefits_of the _muda_water_catchment.pdf.

[9] Wahab, N. A., Kamarudin, M. K. A., Gasim, M. B., Umar, R. Ata, F. M., \& Sulaiman, N. H. (2016). Assessment of total suspended sediment and bed sediment grains in upstream areas of Lata Berangin, Terengganu. International Journal on Advanced Science, Engineering and Information Technology, 6(5), 757-763.

[10] Bilotta, G. S., \& Brazier, R. E. (2008). Understanding the influence of suspended solids on water quality and aquatic biota. Water Research, 42(12), 2849-2861.

[11] Toriman, M. E., At, F. M., Kamarudin, M. K. A., \& Idris, M. (2015). Bed-load sediment profile and effect of river bank erosion on river cross-section. American Journal of Environmental Sciences, 9(4), 292-300.

[12] Kamarudin, M. K. A., Toriman, M. E., Syed Abdullah, S. M., Idris, M., Jamil, N. R., \& Gasim, M. B. (2009). Temporal variability on lowland river sediment properties and yield. American Journal of Environmental Sciences, 5(5), 657-663.

[13] Department of Irrigation and Drainage Malaysia (DODM). (2006). Design Option of the Flood Mitigation Plan of Sungai Muda, Sungai Muda, Kedah. DODM.

[14] Amri Kamarudin, M. K., Idris, M., \& Toriman, M. E. (2013). Analysis of Leptobarbus hoevenii in control environment at natural lake. American Journal of Agricultural and Biological Science, $8(2), 142-148$.

[15] Julien, P. Y., Ab. Ghani, A., Zakaria, N. A., Abdullah, R., \& Chang, C. K. (2010). Case study: Flood mitigation of the Muda River, Malaysia. Journal of Hydraulic Engineering, 136(4), 251261.

[16] Maizan M., \& Ramzan N. M. (2017). Pahang flood disaster: The potential flood drivers Malaysian. Journal of Geosciences, 1(1), 34-37.

[17] Kamarudin, M. K. A., Toriman, M. E., Rosli, M. H., Juahir, H., Aziz, N. A. A., Azid, A., \& Sulaiman, W. N. A. (2015). Analysis of meander evolution studies on effect from land use and climate 
change at the upstream reach of the Pahang River, Malaysia. Mitigation and Adaptation Strategies for Global Change, 20(8), 1319-1334.

[18] Din, H. M., Toriman, M. E., Mokhtar, M., Elfithri, R., Aziz, N. A. A., Abdullah, N. M., \& Kamarudin, M. K. A. (2012). Loading concentrations of pollutant in Alur Ilmu at UKM Bangi campus: Event mean concentration (EMC) approach. Malaysian Journal of Analytical Sciences, 16(3), 353-365.

[19] Kamarudin, M. K. A., Toriman, M. E., Sulaiman, N. H., Ata, F. M., Gasim, M. B., Muhamad, A., Yusoff, W. A., Mokhtar, M., Amran, M. A., \& Abd Aziz, N. A. (2015). Classification of tropical river using chemometrics technique: Case study in Pahang River, Malaysia. Malaysian Journal of Analytical Sciences, 19(5), 10011018 .

[20] Jaafar, O., Toriman, M. E. H., Idris, M. H., Sharifah Mastura, S. A., Juahir, H. H., Aziz, N. A. A., Kamarudin, K. A., \& Jamil, N. R. (2010). Study of water level-discharge relationship using Artificial Neural Network (ANN) in Sungai Gumum, Tasik Chini Pahang Malaysia. Research Journal of Applied Sciences, 5(1), 20-26.

[21] Toriman, M. E., Gasim, M. B., Yusop, Z., Shahid, I., Mastura, S. A. S., Abdullah, P., Jaafar, M., Aziz, N. A. A., Kamarudin, M. K. A., Jaafar, O., Karim, O., Juahir, H., \& Jamil, N. R. (2012). Use of $137^{\mathrm{Cs}}$ activity to investigate sediment movement and transport modeling in river coastal environment. American Journal of Environmental Sciences, 8(4), 417-423.

[22] Kamaruddin, A. F., Toriman, M. E., Juahir, H., Zain, S. M., Rahman, M. N. A., Amri Kamarudin, M. K., \& Azid, A. (2015). Spatial characterization and identification sources of pollution using multivariate analysis at Terengganu River Basin, Malaysia. Jurnal Teknologi, 77(1), 269-273.

[23] Kamarudin, M. K. A., Toriman, M. E., Idris, M., Juahir, H., Azid, A., Gasim, M. B, Umar, R., Endut, A., Mokhtar, M., Khalit, S. I., Ismail, A., Yaakob, N. H. M., \& Rwoo, M. A. (2016). Environmental management on natural lake using sediment and hydrology hydraulic models. Malaysian Journal of Applied Sciences, 1(2), 9-26.

[24] Wahab, N. A, Kamarudin, M. K. A., Anuar, A., Ata, F. M, Sulaiman, N. H., Baharim, N. B., Harun, N. S., \& Muhammad, N. A. (2017). Assessments of lake profiling on temperature, total suspended solid (TSS) and turbidity in the Kenyir Lake, Terengganu, Malaysia. Journal Fundamental Applied. Science. 9(2S), 256-278. 